\title{
Evaluating the Contribution of the Most Common Types of Damage on the Degree of Technical Wear of Masonry Buildings Located in Mining Areas**
}

\section{Introduction}

In mining areas buildings are subjected to additional interactions in the form of surface deformation and mining tremors. These effects may cause damage to building elements located within their impact area.

The degree of damage as well as the natural wear of particular elements of a building (both structural and secondary ones) contribute to its technical wear. The resulting damage means an increase in the degree of technical wear, which can be interpreted as a decrease in utility functions or in value of the building. In the case of a development in mining areas, this increase may reduce the resistance of a building to the effects of mining impacts, which in some cases means a security risk.

Within the analyses presented in this article, the most common categories of damage to masonry residential buildings were determined in the first place. A 4-point qualitative scale was applied to evaluate the extent and frequency of each category of damage.

Then, subject to the collected database, contribution of each category of damage to the extent of technical wear in the analyzed buildings was defined. The study was conducted applying a multiple regression analysis using the STATISTICA program.

\section{Database of the Buildings}

A database including 122 single-family residential buildings of traditional masonry construction, not older than 26 years, located in the Upper Silesian Coal Basin was the base of the research. In the past, these structures were subject to

* AGH University of Science and Technology, Faculty of Mining Surveying and Environmental Engineering, Krakow, Poland

** The article was prepared within the scope of the AGH statutory research no. 11.11.150.005 
repeated impacts of mining exploitation carried out by the nearby mines. These impacts were mainly revealed in the form of continuous subsidence troughs, with rates of deformation variable in time and in particular regions. The rate values have largely remained at the level of categories I and II, and locally reached category III of the mining area.

The database includes information about the technical condition, structure, potential causes of construction failures, as well as the history and extent of the carried out repair works and the potential works securing against mining impacts. Data on the buildings was collected during a detailed inventory, carried out a few years ago as part of the research conducted at the Department of Geodetic Engineering and Construction of AGH University of Science and Technology.

In the study group, detached buildings constitute $60 \%$, the rest is semi-detached. All the structures are at a constant level, they have basements in most cases. The buildings have concrete footings, on which load-bearing walls are supported, built of clay bricks and hollow blocks or concrete blocks. In the analyzed structures, monolithic reinforced concrete floors or suspended beam and block floors, as well as flat bipartite roofs, were mostly used. All the structures, for preventive reasons, were protected against mining impacts during the construction phase (including 53 units for the category III of land and 69 units for the category IV). Most of the buildings from the very beginning were subjected only to minor maintenance works and current repairs.

The degree of technical wear $s_{z}$ was determined individually for each structure. The widely accepted and proven weighted average method was used for the evaluation. It is based on an individual evaluation of the degree of wear of particular elements, and then, by applying appropriate weights, determining a weighted average of the degree of the building wear (e.g. [7]):

$$
s_{z}=\sum_{i=1}^{n} \frac{u_{i} \cdot s_{e i}}{100}
$$

where:

$u_{i}$ - a percentage of the replacement cost of a given element in the structure of the replacement cost of the entire building, acting as a weight,

$S_{e i}-$ a percentage of the wear of a given element,

$n$ - a number of evaluated elements in the building.

Technical wear is a measure of the technical condition of a building. The connection between the technical condition $s_{t^{\prime}}$ usually given in the form of verbal description (from "very good" to "very bad"), and the degree of the building wear $s_{z}$ is usually presented as:

$$
s_{t}=100-s_{z}[\%] .
$$




\begin{tabular}{|c|c|c|c|c|c|c|c|c|c|c|c|}
\hline & 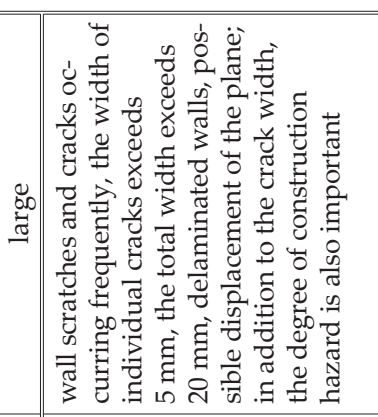 & 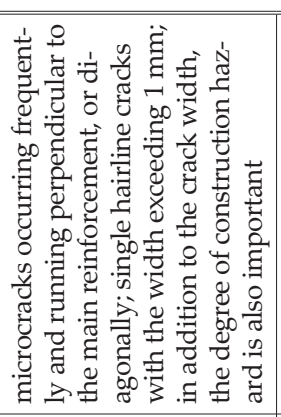 & 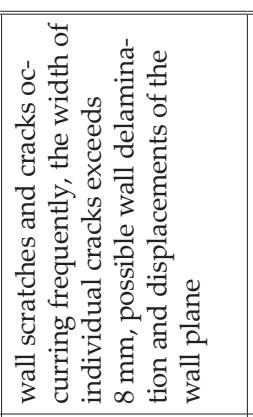 & 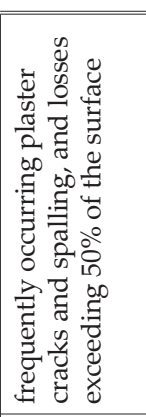 & 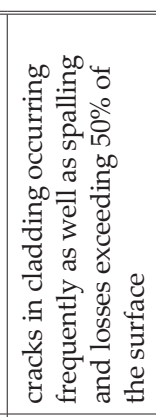 & 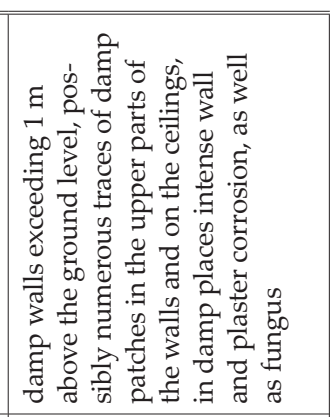 & 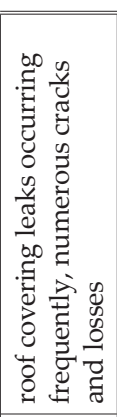 & 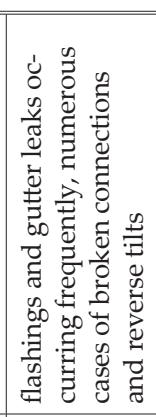 & 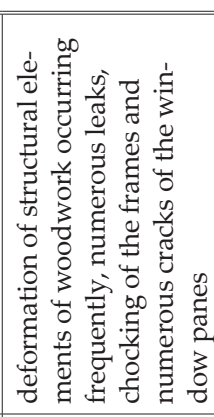 & 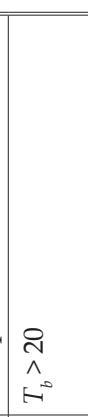 & 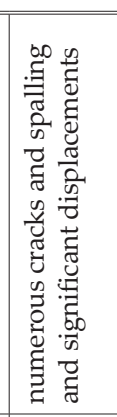 \\
\hline 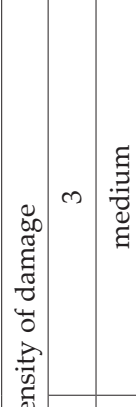 & 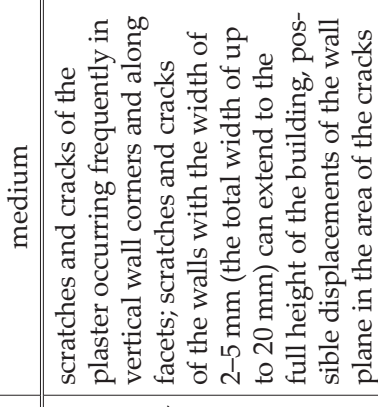 & 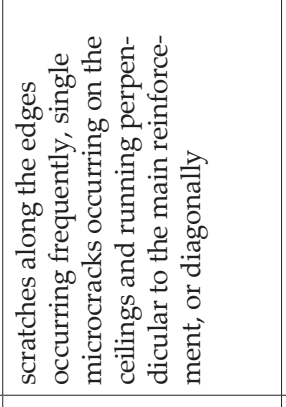 & 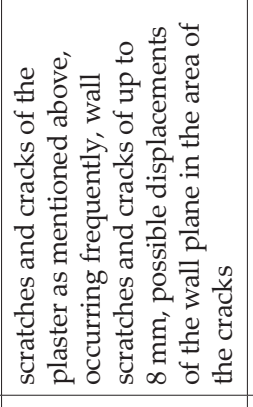 & 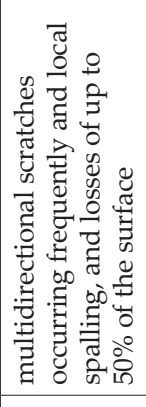 & 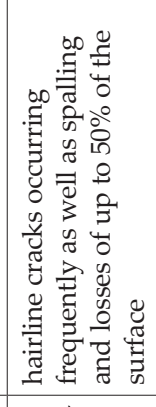 & 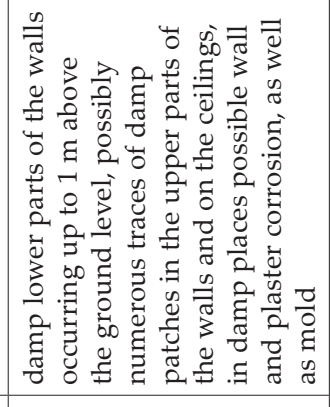 & 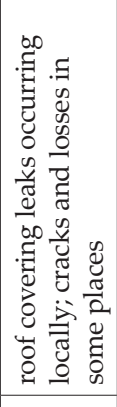 & 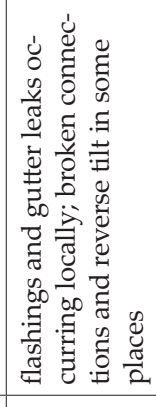 & 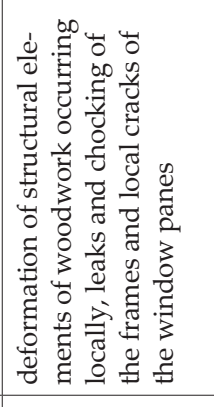 & 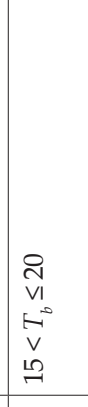 & 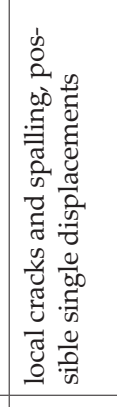 \\
\hline 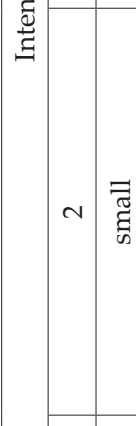 & 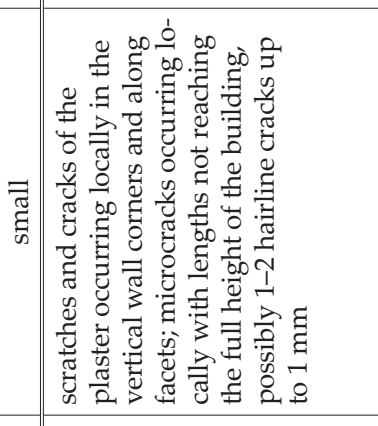 & 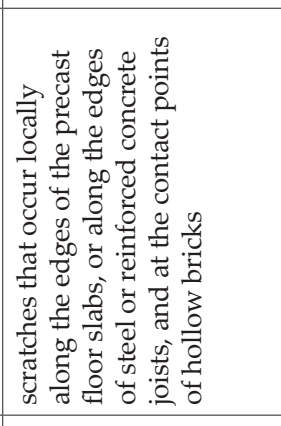 & 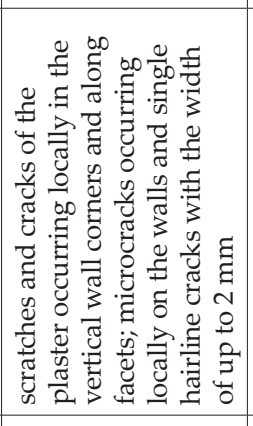 & 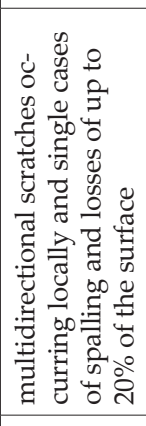 & 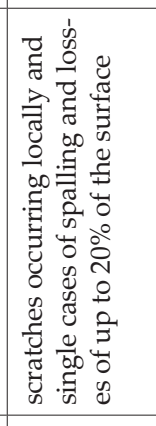 & 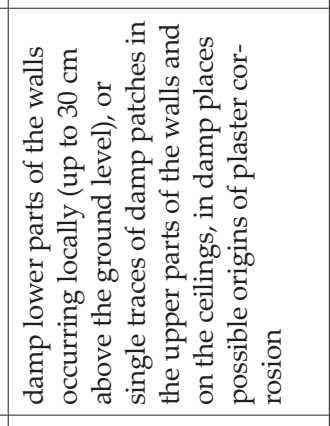 & 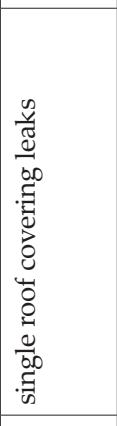 & 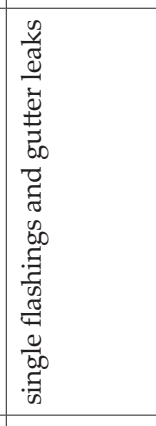 & 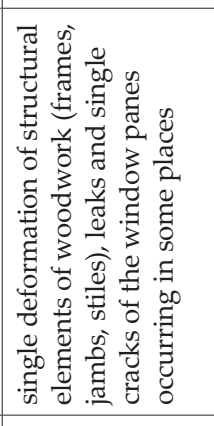 & 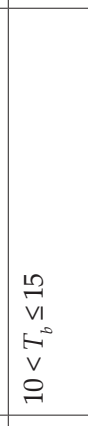 & 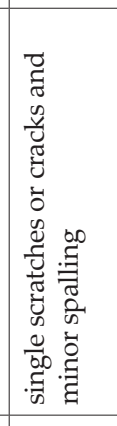 \\
\hline & 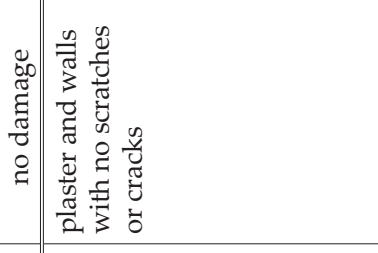 & 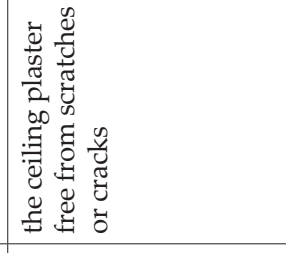 & 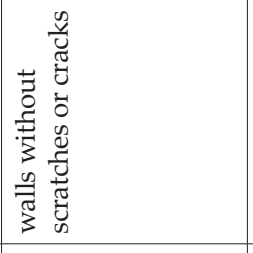 & 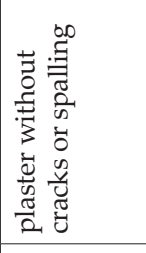 & 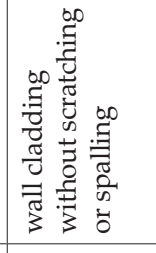 & 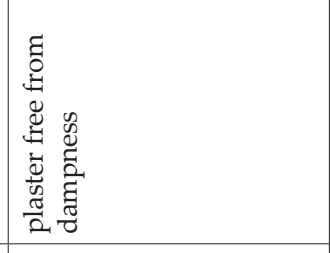 & 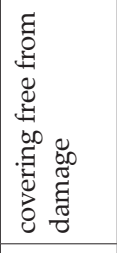 & 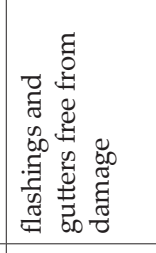 & 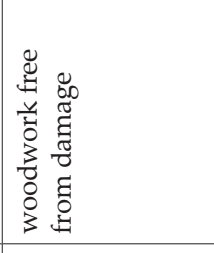 & 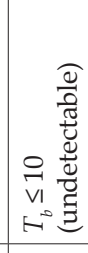 & 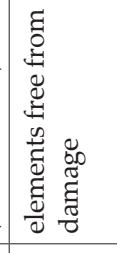 \\
\hline 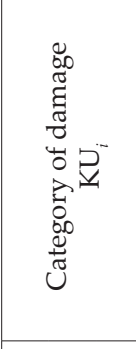 & 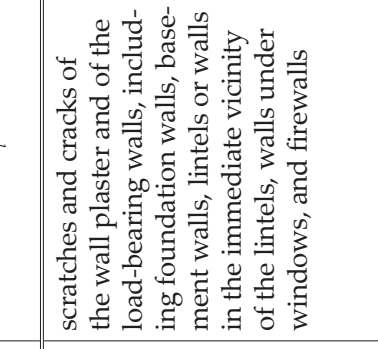 & 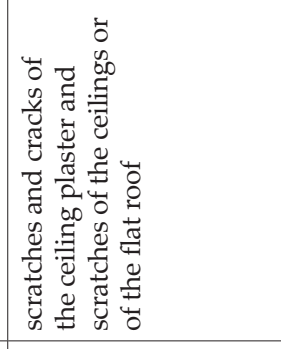 & 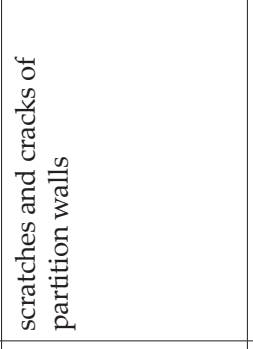 & 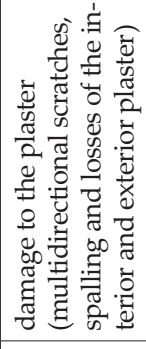 & 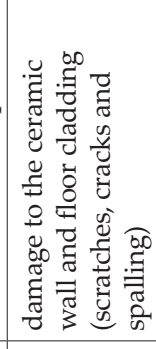 & 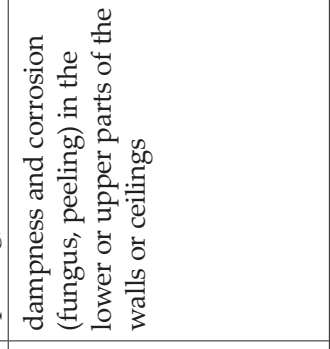 & 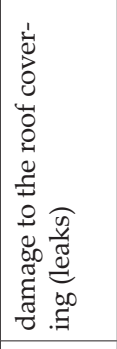 & 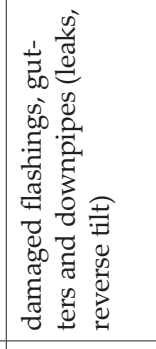 & 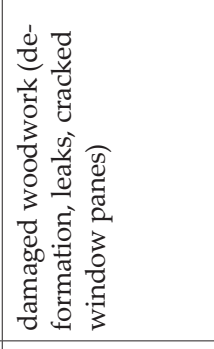 & 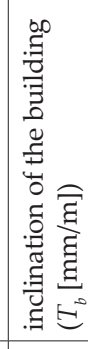 & 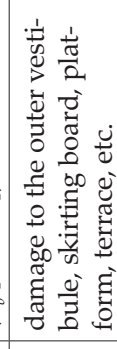 \\
\hline$\dot{z}$ & - & $\sim$ & m & r & ю & 0 & $\wedge$ & $\infty$ & a & 용 & $F$ \\
\hline
\end{tabular}


Taking into account the age and carried out maintenance works, it was concluded that the examined buildings are mostly $(70 \%)$ in good technical condition $\left(s_{z} 11 \%\right.$ to $20 \%$ ), only 15 units are in very good condition ( $s_{z}$ up to $10 \%$ ) and 22 units are in satisfactory condition ( $s_{z}$ from $21 \%$ to $30 \%$ ). The average degree of wear of the analyzed buildings amounts to $16.2 \%$.

\section{The Intensity of Building Damage}

The degree of the building wear, in addition to the natural wear, also depends on the intensity, i.e. the extent and frequency of damage to all of its elements, both structural and finishing, as well as fittings (installations). The common feature of this damage is the fact that their reasons should be sought in factors, which are random in the statistical sense, such as the effects of design and implementation errors, overloading of structural elements, vibrations related to transport or operation of machinery and equipment, changes in hydrographic conditions in the foundation soil, mass rock movements, etc. They also include mining impacts, both as tremors and continuous surface deformation. Taking into account all structural and nonstructural elements of a masonry building, and also systematizing repetitive cases, 11 categories of damage and construction irregularities were distinguished.

Then, in order to perform a qualitative analysis, a four-point scale for evaluating the intensity of damage was proposed:

1 - no damage,

2 - low intensity,

3 - medium intensity,

4 - high intensity.

Table 1 includes a description of individual categories of damage as well as specific criteria for determining the subsequent degrees in the adopted intensity scale. When defining the degree of intensity of damage to individual elements, literature on the diagnostics of technical condition of buildings allowing the specificity of mining areas was used (e.g. [1-3, 5-7]).

\section{Evaluating the Contribution of Each Category of Damage to the Degree of Technical Wear of the Studied Buildings}

\subsection{Research Methodology}

Multiple regression method allows to study the combined effect of several independent variables (explanatory variables) on the dependent variable (response variable). Multiple regression procedure adjusts the plane expressing the relationship between the dependent and independent variables. For this purpose, a linear relationship between the variables in the equation and the normal distribution of 
residuals is assumed. Failure to comply with these principles may lead to incorrect conclusions drawn from the analysis.

Verification of the above assumptions can be based on the analysis of the distribution of residuals (histogram of the residuals) and the normality plot of the residuals. This plot is formed by ranking the residuals based on their values. Then, on the basis of the ranks, variable quantiles of standardized normal distribution are selected (on the $\mathrm{Y}$ axis of the plot). If the residuals of the (on the $\mathrm{X}$ axis) have a normal distribution, then all the points on this plot should be laid along the straight line. If there is no matching, if the points are arranged in a regular shape around a straight line, it means that the residuals are not normally distributed.

The normality plot of the residuals also reveals outliers that may significantly influence the result. According to most sources, if a given observation stands out of the range for more than \pm 3 standard deviations from the mean value, then such a case should be removed from the analysis (e.g. [4]).

As a result of the multiple regression analysis we obtain the multiple correlation coefficient $R$ and the determination coefficient $R^{2}$, the regression coefficients $(B)$ and the regression coefficients (BETA). The value of the BETA coefficients allows to compare the relative contributions that each of the independent variables brings to predict the dependent variable.

The results of the analysis also present the significance level of the correlation $p$. The significance level is the probability of the authenticity of a given hypothesis, which assumes a lack of relationship between correlated random variables. It was assumed that the relationship exists if the significance level $p$ does not exceed 0.05 .

\subsection{Results of the Analysis}

In the analyzed case, the multiple regression method was used to evaluate the contribution of each category of damage $\left(\mathrm{KU}_{i}\right)$, i.e. the independent variables in the dependent variable, i.e. the degree of technical wear $s_{z}$ of the studied buildings. The study group consisted of 122 selected residential buildings, not older than 26 years, of similar architectural as well as construction and material solutions, and located in areas affected by mining impacts of the Staszic coal mine.

During the preliminary studies, the values, the histograms and scatter plots of all the variables were analyzed, and their correlations were examined.

As a result of the preliminary analyses, four independent variables or categories of damage were included in the studies on the impact of the dependent variable $s_{z^{\prime}}$ namely:

- scratches and cracks of the wall plaster and the load-bearing walls $\left(\mathrm{KU}_{1}\right)$,

- scratches and cracks of the ceiling plaster and the ceilings or the flat roof $\left(\mathrm{KU}_{2}\right)$,

- damage to the plaster $\left(\mathrm{KU}_{4}\right)$,

- damage to the outer vestibule, skirting board, platform, terrace, etc. $\left(\mathrm{KU}_{11}\right)$. 
A detailed description of the categories of damage mentioned above has been presented in section 3 , and the obtained results have been summarized in Table 2 .

Table 2. The results of the studies of a dependence of technical wear $s_{z}$ on each category of damage by using multiple regression method

\begin{tabular}{|c|c|c|c|c|c||}
\hline $\begin{array}{c}\text { Factor } \\
\text { (independent } \\
\text { variable) }\end{array}$ & $\begin{array}{c}\text { Standardized } \\
\text { regression } \\
\text { coefficient } \\
\text { BETA }\end{array}$ & $\begin{array}{c}\text { Coefficient } \\
\text { of the } \\
\text { independent } \\
\text { variable } \\
B\end{array}$ & $\begin{array}{c}\text { Significance } \\
\text { level } \\
p\end{array}$ & $\begin{array}{c}\text { Correlation } \\
\text { coefficient } \\
R\end{array}$ & $\begin{array}{c}\text { Determination } \\
\text { coefficient } \\
R^{2}\end{array}$ \\
\hline $\mathrm{KU}_{1}$ & 0.417 & 0.035 & 0.000 & \multirow{2}{*}{0.74} & \multirow{2}{*}{0.53} \\
\cline { 1 - 4 } $\mathrm{KU}_{2}$ & 0.131 & 0.011 & 0.050 & & \\
\cline { 1 - 3 } $\mathrm{KU}_{4}$ & 0.253 & 0.019 & 0.000 & & \\
\hline $\mathrm{KU}_{11}$ & 0.340 & 0.022 & 0.000 & & \\
\hline absolute value & - & -0.008 & 0.600 & & \\
\hline
\end{tabular}

From the results of the research presented in Table 2 it is evident that the analyzed factors (categories of damage) jointly explain about $53 \%$ of the variation of technical wear of the studied buildings.

The values of the standardized regression coefficients (BETA) indicate that damage to the wall plaster and to the bearing walls, i.e. category $\mathrm{KU}_{1}(42 \%, p<0.000)$ has the relatively greatest impact on the degree of wear. Scratches and cracks of the ceiling plaster as well as of the ceilings or the flat roof, i.e. $\mathrm{KU}_{2}$, have the smallest effect $(13 \%, p<0.00)$.

\section{Summary}

In order to evaluate the extent and frequency of common categories of damage, the studies presented in the article applied a qualitative scale ( 1 - damage does not occur, 2 - little damage, 3 - medium, 4 - large). The values of the intensity of damage have been determined individually for each of the 122 analyzed buildings, separately for each category.

From the carried out analyses it is apparent that the accepted categories of damage jointly explain about $53 \%$ of the variation of technical wear of the studied buildings. In this, damaged wall plaster and the load-bearing walls have relatively the greatest (about 40\%) impact on the degree of wear. Scratches and cracks of the ceiling plaster as well as of the ceilings or the flat roof have the smallest effect.

The above results prove that, for example, damage to the load-bearing walls have an average of about $20 \%$ contribution to the degree of wear of the analyzed buildings. 
In interpreting the described study results it should be remembered that the analyzed buildings are mostly in good technical condition (70\% of cases), and their average wear amounts to $16.2 \%$.

The presented method of description and evaluation of the intensity of the various types of damage can be used to assess the phenomenon on a global scale. If there is a need to inspect the safety of a particular building, individual evaluation is required.

\section{References}

[1] Firek K.: Badanie wpływu czynników górniczych i budowlanych na zużycie techniczne tradycyjnej zabudowy terenu górniczego LGOM. Akademia Górniczo-Hutnicza, Kraków 2005 [Ph.D. thesis].

[2] Hajdasz H.: Sposoby ustalania zużycia technicznego budynków i budowli. Katowice 1992.

[3] Instrukcja GIG nr 12. Zasady oceny możliwości prowadzenia podziemnej eksploatacji górniczej z uwagi na ochronę obiektów budowlanych. Główny Instytut Górnictwa, Katowice 2000.

[4] Stanisz A.: Przystępny kurs statystyki z zastosowaniem STATISTICA PL na przykładach z medycyny. StatSoft Polska, Kraków 2007.

[5] Wodyński A., Barycz S.: Analiza porównawcza stanu technicznego i zakresu uszkodzeń budynków na terenie górniczym LGOM. Materiały Szkoły Eksploatacji Podziemnej 2002, Sympozja i Konferencje, nr 54, PAN/AGH, Kraków - Szczyrk 2002.

[6] Wodyński A, Kocot W.: Metodyka oceny stanu technicznego budynków o tradycyjnej konstrukcji zlokalizowanych na terenach górniczych. Przegląd Górniczy, nr 7-8, 1996, pp. 16-19.

[7] Wodyński A.: Zużycie techniczne budynków na terenach górniczych. Uczelniane Wydawnictwa Naukowo-Dydaktyczne AGH, Kraków 2007. 